\title{
Motivations for and Comparisons of Green Certificates within the Hotel Industry ${ }^{i}$
}

\author{
Pernille Eskerod ${ }^{*}$, Jovana Đurić \\ Department of Business \& Management, Webster Vienna Private University, Praterstraße 23, A-1020 Vienna, Austria \\ *Corresponding Author: pernille.eskerod@webster.ac.at
}

Copyright $@ 2018$ by authors, all rights reserved. Authors agree that this article remains permanently open access under the terms of the Creative Commons Attribution License 4.0 International License

\begin{abstract}
A blooming hotel industry has the downside of an increased negative environmental impact. At the same time, many hotel guests and employees have become conscious of eco-friendliness and green practices. In addition, 2017 was by United Nations declared as the International Year of Sustainable Tourism for Development, with the emphasis on (among other elements) resource efficiency and environmental protection. A hotel that has obtained green certificate(s) promises green services, products, and operations, and possesses thereby (potentially) important strategic assets, when it comes to attracting customers and employees. Many green certifications are offered within the hotel industry, such as for example Green Globe and Green Key. However, which certificate(s) to choose is a strategic choice for the hotel management. In this paper, we examine green certifications in order to determine similarities and differences among them. As part of the research, we analyze the usage of green certificates in different regions (e.g. Southeast Europe). Even though many of the certifications are offered internationally, we identified clear differences in dissemination across regions. In addition to region, our motivation factor analysis shows that belonging to a hotel chain/brand seems to be highly influential on the choice of certificate(s).
\end{abstract}

Keywords Green Certificates, Eco-friendliness, Sustainability, Hotel Industry, Strategic Asset, Strategic Choice, Motivation

\section{Introduction}

The hospitality industry is one of the world's largest and most important industries. It's more than evident that the extent of travels, international conferences and overnight stays has increased significantly and will continue to rise. The industry is not only recognized as a rapidly developing one, but also regarded as one of the most attractive businesses as emphasized by Pizam and Shani [1].

Parallel to this, eco-friendly options are welcomed within the hospitality industry, where e.g. both hotels and airplanes opt for greener solutions. The hotel industry is often associated with large energy consumption, food waste, carbon emissions and lots of chemicals for washing and cleaning, while at the same time, many hotels encounter an increasing number of hotel and conference guests that request more sustainable solutions from their accommodations. Martin-Pena et al. [2] initiated a study to investigate the motivations for hotels to go for green certification(-s). The study found that green certification may be sought by hotels due to a number of different benefits (e.g. cost saving and an effective environmental management system) associated with it.

With this background it seems evident that there is a big potential for the hotel industry to rethink business models and services aiming to reduce the consumption and waste, and to increase the sustainability oriented experiences of the hotel guests. The emergence of concerns over global climate change has led to a growing attention towards green activities as stated in the recent research [3]. A new research project [4] shows that sustainability in the industry concerns more than saving kilowatt hours - it is as much about the combined care for the environment and for the guest. Therefore, as Borella and Rodrigues [5] argue, obtaining a green certificate acts as a clear indication that a hotel is committed to improve its reputation, environmental management strategies, environmental legitimacy, and customer attraction. This is consistent with the assertions by De Jong et al. [6] that ideology, reputation, marketing, and economic motives are among the key factors considered by hotel managers before going for a green certification. As the most recent study shows [7], hotels fear losing their domestic and international reputations when they fail to uphold environmental conservation standards, thus they want to demonstrate that they are doing so by gaining green certification. Generally, this creates an effective green corporate image.

It is claimed by Thomsen [4] that the development 
towards increased sustainability helps to increase profits, create more jobs and new business opportunities for the hotel industry. Among others, Graci and Dodds [8] listed in detail the positive effects of "going green", and these include gaining competitive advantage by being a leader in the sector, customer loyalty, employee retention, awards and recognition, increased brand value, risk management, and more. He et al. [9] support this statement by arguing that engaging in green strategies has a potential of enhancing a hotel's competitive advantage. For this reason, thousands of hotels within the hotel industry's leading chains are now required to report their environmental impact to headquarters. This is especially practiced in developed countries with the attempt to protect the natural capital through improvements in existing environmental standards within the industry as stated in Sasidharana et al.'s [10] research. According to Hasek [11], more sustainability reporting is taking place at the corporate level, and the industry has been in agreement on how to calculate the carbon impact of hotel stays and meetings since 2012 .

There are many statements supporting the sustainability importance e.g. the World Tourism Organization (UNWTO) Secretary-General, Dr. Rafai, indicated in 2015 that "[there is a] unique opportunity to advance the contribution of the tourism sector to the three pillars of sustainability - economic, social and environmental, while raising awareness of the true dimensions of a sector which is often undervalued" [12]. In addition, the year 2017 was by United Nations declared for International Year of Sustainable Tourism for Development with the emphasis on (among other elements) resource efficiency and environmental protection.

Our own interest in this research stems from the fact that we have observed a rapidly increasing interest within hotel management of many hotels to let the hotel certify (or by some certification bodies called 'be awarded') with green certificates. A hotel that has green certification(s) promises more green services, products, and operations, and possesses thereby (potentially) important strategic assets, when it comes to attracting customers and employees. However, many different green certifications are offered within the hotel industry, such as for example Green Globe and Green Key. The choice of which certificate(s) to select is a strategic choice for the hotel management. There are gaps in the literature when it comes to factors that cause hotel management to decide for a specific certificate, as well as challenges and practices when it comes to implementation of changes in services, products and operations. Further, as Borella and Rodrigues [5] observe, there is not much literature on the trends of green certification especially within the hotel industry.

This study proposes to inform the debate regarding green certificates by investigating the specific motivations of businesses in becoming certified.

As a first step to understand which factors that influence managers' decisions to obtain a particular type of certification, we aimed to identify and classify different types of green certifications, and determine their similarities and differences. Further on, we investigated dissemination of the various certificates across regions.

In sum, the research aimed to answer the following questions:

- What are the motivation factors for green certifications?

- What is the usage within the hotel industry in various regions (e.g. Southeast Europe) of different global green certificates?

- What are the similarities and differences among global green certificates/certifications within the hotel industry?

The paper is structured as follows: First, the theoretical framework is presented. Hereafter follows a section on research methodology. Next, a section on findings is presented and, finally, a conclusion, limitations and suggestions for further research are offered.

\section{Literature Review}

Weeden [13] stated that in almost four decades numerous debates regarding the importance of global sustainable development have taken place. However, only since the 1990s the hospitality industry has been pursuing and adopting a significant number of green practices, as a result of fluctuating economic levels and a strong focus on customer service and satisfaction [14]. It appears that many travelers around the world now prefer so-called green hotels as emphasized by Chan [15]. Using the label "green hotel" has typically the purpose of playing a critical role in customers' decision-making processes and behavioral intentions [16] and thereby as Pizam indicates [17] attract potential customers, Knuth is adding [18], evaluate whether a hotel is eco-friendly or not before booking.

Positive attitude towards green certification is not only seen from guests but also from hotels themselves. The rising environmental awareness has triggered more hotels to invent green solutions that not only satisfy the demands of their customers but also improve their profit maximization levels [5]. Hence, obtaining a green certificate indicates a hotel's intention to engage in green activities during its operations and food production processes. According to Kasim [19], leading hotel chains in Western Europe and North America consider green marketing as a tool to position their companies in the market, to differentiate their companies' products and services from those of its competitors and to create trustful relationships with their environmentally conscious non-governmental organisations, market intermediaries (e.g. tour operators), the public and most importantly their guests.

Luan et al. [20] claim that most organizations have 
adopted the certification either by pressure from external stakeholders or business partners. They are continuing that basically, the demand from shareholders, environmental lobby groups, customers and the neighbouring society affects a firm's decisions in this respect.

In order to understand the purpose of the concept of certification itself, Black and Crabtree [21] suggested an extensive definition of certification i.e. "voluntary procedure that sets, assesses, monitors, and gives written assurance that a product, process, service, or management system conforms to specific requirements and norms. A certification/awarding body gives written assurance to the consumer and the industry in general. The outcome of certification is a certificate and usually the use of an ecolabel." (p. 502)

Going Green has become the "it" topic of concern of the past several years and continues to gain attention [22]. According to Green Globe [23], never before has the need for businesses to operate in an environmentally responsible manner been so evident. Many businesses nowadays seek to implement programs that demonstrate their commitment to sustainability as a major part of their Corporate Social Responsibility (CSR) policies, consequently constantly growing multi-billion dollar industries like sustainability related products, services and consulting. There are even proactive green companies, implementing green certifications voluntarily in order to avoid social critics. For example, international chain hotels use code of conduct and training in order to foster ethical environment as stated in study of Dief and Font [24].

Based on the studies by Borella and Rodrigues, Luan et al. and López-Gamero et al. [5, 20, 25], there are empirical evidence on the impacts of green activities on organizational performance. Other studies also showed the beneficial effects of a green certificate as well as a constantly growing tendency for using it. For instance, Gagiolli [26] stated that "the eco/green/environmentally friendly movement has become popular and shows no sign of stopping. Not only guests are becoming more and more knowledgeable about green practices, but also they are creating certain expectations from the hotels in requesting them to possess the certificate. This being the case, their decision between booking one property over another depends on their eco-friendliness." Therefore, third-party certificates can help a hotel attract customers. Gagiolli [26] supported his previous claims by adding that "obtaining a certification, especially one completed by a third-party auditor, will help confirm [the] team's effort, as well as convince guests [that the hotel's] eco-claims are valid". Similarly, Fukey and Issac [27] discussed the benefits of green management, stating that many hotels profited from enhanced reputation of the firm and more worth customers, however the financial saving are the most essential reason when it comes to an implementation decision. The reduction in cost for posting advertisements is beneficial, and the clear orientation of the hotel might increase employees' recognition of the workplace. So, not only consumers can see the values of green certification, but also current and potential employees. As Fukey and Issac [27] state: "sustainability in business is the growth in lively processes which enable people to understand the potential to protect the Earth's existent support systems" (p. 296). Moreover, according to $\mathrm{Li}$ et al. [28], attracting potentially good employees who are proud of working in an environmentally conscious organization may be a motive behind the acquisition of green certification by hotels. All these claims of green benefits are also supported with the numbers. For instance, large scale dataset from PKF Hospitality Research on the U.S. hotel industry [29] shows that eco-certified hotels recorded higher operations-driven and customer-driven resource efficiency.

Sedmak [30] pointed to another perspective of how green certificates can be valuable for the hotels. Green certifications represent a way to enhance consistency on the company level because: (1) it is guiding managers and employees, and (2) it is aligning expectations of customers and even suppliers (both existing and potential).

Conversely, despite its 'perceived' potential benefits, the importance of green certification has received much criticism from scholars such as De Jong et al., He et al., Knuth and Luan et al. $[6,9,18,20]$. On the same note, other scholars have found that obtaining a green certificate and implementation of environmental management systems may not have any positive effect on the performance of an organization. For instance, evidence by Dippold et al. [31] reveals a weak positive relationship between green certification and financial performance of firms. Furthermore, studies by Granly and Welo [32] reveal that besides legitimacy, credibility, and external recognition, green certification has only trivial value to hotel organizations. Finally, there are big concerns when talking about ecotourism and sustainable tourism which can be considered as green wash [33].

In order to achieve all the positive effects hotels are required to comply with a lot of strict rules and regulations, policies and procedures. For instance, most of the hotels have instituted a changing towel policy e.g. not to replace them unless it is requested, as indicated by Fukey and Issac [27]. It is essential to provide special training to all the employees and offer them training programs about the environment. From the point of view of customers, Fukey and Issac [27] considered that some guests are not willing to pay more to support a hotel's green initiative. This can be very risky for the hotels, as if they invest in the implementation, they might not only spend extra money e.g. on ecological raw food ingrediates, but lose guests as well. Another factor that prevents positive effects can be low visibility of the certificate, which makes both employees and guests unaware [34]. An example supporting this claim would be 'low general environmental awareness' as well as 'lack of publicity' as listed by Tsai et al. [35]. After analyzing Island Shangri-La, the first hotel in Asia to 
obtain the ISO 14001 certification, the researchers identified that 'low employee involvement' is one of the major issue. After the employees realized that they were not directly affected by the green certification, which at the same time made them work even more, they tended to lose focus. The authors noticed that 'lack of government and industry support' can be some of the reasons when facing challenges with green management. An experimental study [36] indicates that "positive attitudes towards ecolabels are an unreliable predictor of responsible environmental tourist behavior" (p. 590).

Overall, due to the limited consumer demand for sustainable travel certification programs, Font [37] concluded that marketing should be aimed at travel intermediaries and affinity groups that are likely to be most responsive to the sustainability message. For instance, co-marketing and affiliations with respected government entities, NGOs, and consumer-oriented companies would be helpful in building consumer recognition [37].

\section{Methodology}

\section{Types of Data}

The research underlying this paper is based on both primary and secondary data. In 2017-2018, secondary data for this study, consisting of websites and newspaper articles, was collected. The purpose of the data collection was to be able to compare dissemination of green certificates in numbers and geographical coverage. Moreover, the theoretical framework is based on research literature on green certifications, the hotel industry and sustainability. Searches have been undertaken through more of the academic databases and search engines, e.g. EBSCO databases, ProQuest, Scopus, and Google Scholar.

Based on the above mentioned data collection, primary data was also collected. A semi-structured interview guide was used as the data gathering tool, and the study was designed as a qualitative research. The interviews were carried out with relevant informants within six hotels in different world regions. (Please note that the hotels are kept anonymous in this paper). The in-depth interview had the purpose to identify reasons of obtaining green certificates. Some of the questions were:

- Which green certificates do you have?

- What are the reasons for implementing green certificates?

- Have you heard about any other green certificates within the hotel industry? If yes, what are in your opinion the potential benefits of other types of certificates? Have you heard about any other hotels which have green certificates?

- What influenced your decision to implement the particular green certificate among all other globally offered green certificates?

\section{Selection of Certificates and Data Analysis}

On a global scale, more than 140 green certification labels exist, e.g. Earth Check, Energy Star, Green Globe, Green Key, Green Key Globe, Green Tourism Active, ISO Standards with ISO 14001 being for Environmental Management, Travelife, Trip Advisor Greenleaders etc. To answer the given RQs within this study, comparison of five certificates was made. The six hotels were selected due to convenience sampling while we wanted to include different regions of the world. Based on the hotels' chosen certificates we investigated following certificates: (1) Green Globe, which according to Gagiolli [26] is one of the most popular/globally recognized green certifications interview done with the Communication and PR Manager in a boutique chain hotel in Denmark; (2) Green Key, with a Chief Engineer at a hotel in Serbia; (3) ISO 14001Environmental Management, as this related to the in-depth interview with the General Manager at a hotel in Serbia and a brief interview with a front desk employee of a Nordic chain hotel in Denmark, (4) Green Leaf related to an interview with the General Manager of a hotel in Maldives, (5) Green Growth 2050 as the interview was conducted with one of the employee of a big hotel chain in Thailand.

In order to determine differences and similarities across the five chosen certificates, different aspects were selected: aim, process of certification, general characteristics, and criteria.

\section{Findings}

In the following sections the answers to the three RQs are provided.

\section{Motivation Factors for Implementing Green Certificate}

In table 1 , an overview of the hotels included in the empirical study as well as some of the major motivation factors for the certificate choices is offered. 
Table 1. Overview of cases in the empirical study

\begin{tabular}{|c|c|c|c|c|}
\hline $\begin{array}{c}\text { Type of hotel \& } \\
\text { Destination }\end{array}$ & Certificate type & $\begin{array}{c}\text { Hotel chain as a } \\
\text { motivation for } \\
\text { certificate choice }\end{array}$ & $\begin{array}{c}\text { Region as a motivation } \\
\text { for certificate choice }\end{array}$ & $\begin{array}{c}\text { Other motivations } \\
\text { mentioned for certificate } \\
\text { choice }\end{array}$ \\
\hline $\begin{array}{c}\text { Boutique hotel chain, } \\
\text { Denmark } \\
\text { Hotel \#1 }\end{array}$ & Green Globe & Yes & $\begin{array}{c}\text { Selected certificate } \\
\text { perceived to have the } \\
\text { strongest requirements }\end{array}$ \\
\hline $\begin{array}{c}\text { Chain hotel, Denmark } \\
\text { Hotel \#2 }\end{array}$ & ISO 14001 & Yes & Yes \\
\hline $\begin{array}{c}\text { Chain hotel, Maldives } \\
\text { Hotel \#3 }\end{array}$ & Green Growth 2050 & Yes & Yes & No \\
\hline $\begin{array}{c}\text { Chain hotel, Serbia } \\
\text { Hotel \#4 }\end{array}$ & Green Key & Yes & Yes & No \\
\hline $\begin{array}{c}\text { Chain hotel, Thailand } \\
\text { Hotel \#5 }\end{array}$ & Green Leaf & Yes & Yes & No \\
\hline $\begin{array}{c}\text { Single hotel, Serbia } \\
\text { Hotel \#6 }\end{array}$ & ISO 14001 & No & $\begin{array}{c}\text { ISO 9001 Standard was } \\
\text { already implemented }\end{array}$ \\
\hline
\end{tabular}

Source: provided by the authors.

The statement of Knuth [18] bring that green certification has the capability of improving the effectiveness and efficiency of hotels has been confirmed in the interviews of all six hotels. Moreover, it also improves their financial performance. However, the interviews reveal different motivation factors within the various hotels. Most motivation factors relate to an aim for better performance. The following progresses based on the certification were seen in the hotel in Maldives: 'Better engagement, regular meetings, PPE [personal protective equipment], food safety' (Hotel \#3, General Manager). Although these achievements, which were aimed for, are already visible, the hotel still does not want to stop here. Hence, in three years they want to work on Waste Management, sustainable training, and use of solar energy. A General Manager (Hotel \#6) stated that some of the implemented practices with green certification such as note for towels and special sensors for lights are very useful when it comes to efficiency improvement.

For hotels in a chain it seems that belonging to a hotel chain/brand significantly influences the given hotel's motivation for and choice of certificate, e.g. due to corporate policy or recommendation. This was observed in all five chain hotels in the empirical study.

For four of the six hotels the region in which the hotels were situated was a motivation factor for the choice of certificate.

For some hotels, gaining green certification means opportunity to join training/seminars, e.g. stated in the hotel in Thailand: '[Green certification is an] opportunity to join training/seminars on environmental educational, environmental standards, and energy efficiency' (Hotel $\#$, Employee). This statement is supported by the General Manager from the hotel in Maldives as it is claimed that Food \& Bevarage, Kitchen, Engineering and HK teams get proper training due to the certification requirements.

Some hotel managers are seeing motivation 'in the value for the hotel itself as they want to differentiate from competitors'. (Hotel \#4, Communication and PR Manager). One of the interviewees pointed to the fact that '[A Green certificate] is definitely a competitive advantage, as big corporation such as Coca Cola and Siemens pay attention on this initiation' (Hotel \#4, Chief Engineer). The Chief Engineer continues '[Big corporations] want to see someone being environmentally responsible' (Hotel \#4, Chief Engineer). This can be interpreted as a connection with the particular hotel and a way to share the same ideas. Also, 'The hotel can make the green certificate visible on their website and guests can check which features the hotel has' (Hotel \#4, Chief Engineer). However, in some countries, only a small percentage of guests (around 5\%) care about certification, especially in not developed countries where guests don't expect to find it.

One interviewee gave a number of motivation factors: 'It's aligned to the hotel's core values'; 'It helps improve hotel operation, environmental plan, green product, human resource and environmental management, minimizing footprint which sometimes can save cost and also benefit the surrounding environment and communities'; and '[green certification is] an opportunity to have our hotel rated and labeled based on predetermined environmental practices and policies and use the certificate as a tool to distinguish from other hotels' (Hotel \#5, Employee).

For one hotel (Hotel \#1) it was mentioned that the motivation for the particular certificate was that it was perceived to have the strongest requirements and therefore would differentiate the hotel the most among the competitors when it came to environmental practices.

In order to understand why top management at a hotel would choose a specific certificate, we asked the General Manager of the only hotel in Belgrade that has implemented the ISO 14001, i.e. an Environmental Management System. The hotel was the first specialized business hotel in Serbia, and in 2017, it was awarded with the Certificate of Excellence by Trip Advisor based on hotel guest reviews. The General Manager stated that "ISO 14001 standard was implemented in 2014 with the desire of the hotel to do business according to the latest world standards which relate to the improvement of business through greater orientation and protection of the area in 
which we work and live." (Hotel \#6, General Manager). Further, they wanted to be ecologically responsible and to improve, additionally, their business and the outcomes of their work. The reason why ISO 14001 was selected among green certificate opportunities was that the hotel already had successfully implemented ISO 9001. This was due to the fact that the hotel owner had other business (outside the service sector), and they were also ISO certified. Therefore, it seemed like a natural choice for the hotel.

Financial motivation factors in the form of reduction in taxes, subsidies etc. were not among the motivation factors mentioned as this was not offered in the particular countries.

\section{Dissemination of Green Certificates across Regions}

Figure 1 offers an overview of the proportion of hotels with green certificate. It shows the density of environmental sustainability certified hotels per continent.

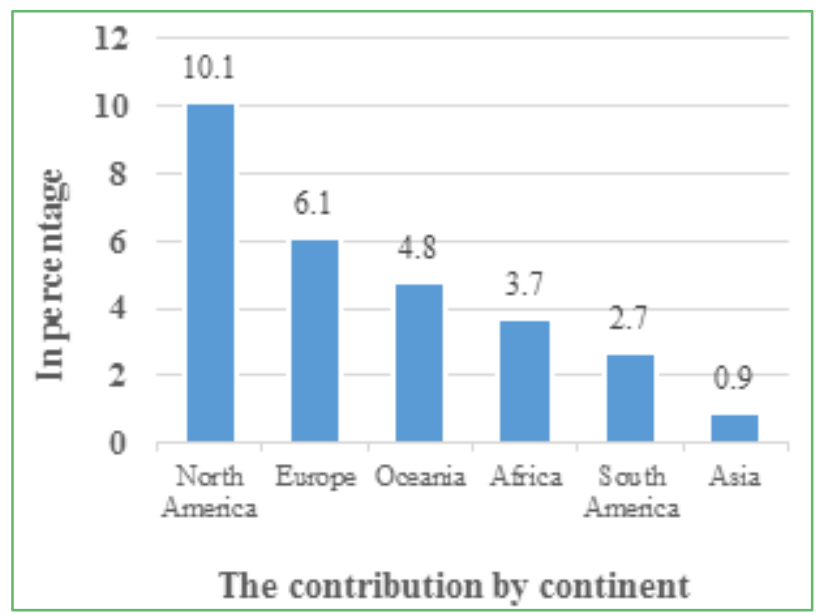

Source: provided by the authors based on International Tourism Partnership data.

Figure 1. Study of $130000+$ hotels worldwide

Figure 1 which is based on a study of $130000+$ hotels worldwide shows that there were $6.2 \%$ hotels certified. It is interesting that Asia, as one of the leading business-growth areas of the world, has the lowest density, however, according to Koeppel [38] 0.9\% of all hotels in Asia with an environmental sustainability certification provides enough potential for improvement, should Asia ever feel the need to match or surpass the \% level of hotels in Europe or North America. Thailand is Asia Pacific's most popular tourist destination according to Sile [39], and may be the place where green certificates can be expected to grow the most. Another example of a segment with high growth potential when it comes to green certificate is the luxury tourism destination - Maldives. As the government has followed a consistent policy of 'quality tourism', it has often been cited as a prime example of sustainable tourism [40].

The second research question concerned the usage of different certificates within various regions. The choices of regions were based on relevance and convenience sampling. We chose Northern Europe (as Green Key was founded in Denmark), Southeast Europe (as two of our hotels are situated in Serbia) and Central Europe (as we as authors are situated in Austria). Please note that unfortunately data were not available for Green Growth 2050. Further, Green Leaf Foundation is only present in Thailand therefore this certificate was not relevant for this part of the study. For Green Globe, we have in Figure 2 calculated number of members, whereas data for ISO 14001 is taken from their database, which is based on data provided by accredited certification bodies (please notice that the database is not fully accurate as non-accredited certification bodies exist, and some of them didn't deliver data to ISO). Obviously, Green Key is the most present in Northern Europe. This may be due to its origin there. When it comes to Southeast Europe, the majority of organizations with Green Key certificates is in Greece. The reason may be that Greece is a well-established tourist destination, and that Green Key is specialized for hotels. The results are presented in Table 2.

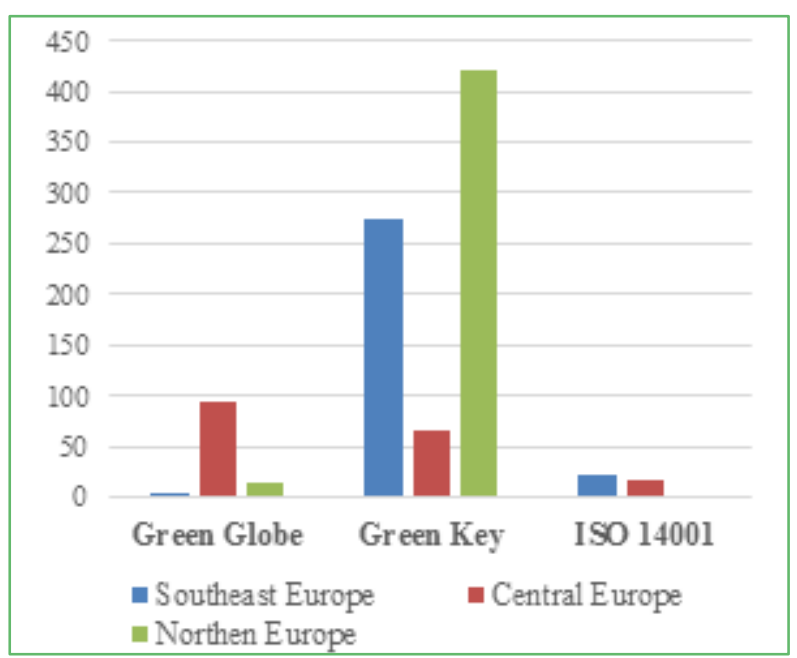

Source: provided by the authors.

Figure 2. The number of certificates in different regions

Table 2. The number of certificates in Southeast Europe per countries

\begin{tabular}{|c|c|c|c|c|c|c|c|c|}
\hline & $\mathrm{AL}$ & $\mathrm{BIH}$ & $\mathrm{BU}$ & $\mathrm{CR}$ & $\mathrm{GR}$ & $\mathrm{MA}$ & $\mathrm{MO}$ & $\mathrm{RO}$ \\
\hline $\begin{array}{c}\text { Green } \\
\text { Globe }\end{array}$ & 0 & 0 & 0 & 0 & 1 & 0 & 0 & 1 \\
\hline $\begin{array}{c}\text { Green } \\
\text { Key }\end{array}$ & 0 & 0 & 1 & 7 & 261 & 0 & 0 & 2 \\
\hline
\end{tabular}

$\mathrm{AL}=$ Albania, $\mathrm{BIH}=$ Bosnia and Herzegovina, $\mathrm{BU}=$ Bulgaria, $\mathrm{CR}=$ Croatia, $\mathrm{GR}=$ Greece, $\mathrm{MA}=$ Macedonia, $\mathrm{MO}=$ Montenegro, $\mathrm{RO}=$ Romania.

Source: provided by the authors.

\section{Similarities and differences among the selected green certificates}

In order to answer RQ 3, comparisons among the five selected certificates were undertaken.

When looking at the year of their establishment, the 
Green Leaf Foundation was founded in 1998 by six organizations from the government sector and private sector in Thailand. Green Key was launched in Denmark by HORESTA (Association of the Hotel, Restaurant and Tourism Industry in Denmark), the Danish Outdoor Council and the Association of Danish Tourism Executives. Green Globe was established over two decades ago. ISO 14001 standard, was developed by the International Organization for Standardization (ISO) in 1996. There is no information available about Green Growth 2050, however, it seems to be the youngest one.

Regarding the standard/governing framework, Green Growth 2050, Green Key, Green Globe and Green Leaf are members of the Global Sustainable Tourism Council (GSTC). GSTC establishes and manages global sustainable standards, known as the GSTC Criteria. They support the GSTC mission of making all tourism more sustainable by increasing the reach of sustainable tourism practices to traditional, small, and large-scale operations and endorse the principles of the GSTC as identified by International Tourism Partnership [41]. On the other hand, ISO 14001 is part of a larger framework, the ISO 14000 family, which enables organizations to voluntarily establish proper standards and systems of environmental management [20]. The certification is developed by the International Organization of Standardization (ISO), a global body responsible for ensuring that proper environmental management systems are put in place to ensure full compliance with international standards for environmental conservation as defined as Environmental Management System [42]. Basically, organizations implement the ISO 14001 certification through the plan-do-check-act (PDCA) approach to ensure that they continuously improve their environmental management systems [43]. Current global statistics by Oliveria et al. [44] on green certification indicate that by the beginning of 2010, 223,149 companies worldwide had already acquired ISO 14001.

The focus of Green Globe is on maximizing economic impact and minimizing social impact by investing in community development, local employment and entrepreneurs and fair trade, while Green Key aims to lower environmental footprints through sustainability management and to raise awareness of sustainability among staff and guests [41]. Further, according to the Environmental Management System [42], the aim of ISO 14001 is to provide organizations with a framework to protect the environment and respond to changing environmental conditions in balance with socio-economic needs.

Based on the description presented above, it is clear that Green Globe is the most general one out of the selected certificates, whereas Green Key is specific for hotels, and Green Growth 2050 meet the needs of tourism and travel industries. ISO 14001 is generally covering all industries, both manufacturing and services. The Green Leaf Program is specific for hotels and it's under the Green Leaf Foundation. Its prime objective is to help hotels improve their efficiency in saving energy, water and other resources. The Green Growth Global Standard was developed by the team at VisionCSR in Australia and Greenearth.travel, based in the EU. It also draws on elements of the ISO 14001 among other standards and international agreements. Green Growth 2050 aims to connect sustainable tourism and CSR [41].

When identifying similarities and differences among the certification processes, it became clear from the certification schemes available online of all the five selected certificates (i.e. Green Globe, Green Key, ISO 14001, Green Leaf and Green Growth 2050) that Green Globe has its own specific stages such as payment of membership, acquiring knowledge about the processes, and implementation of standards (in which minimum 50\% compliance rate with the standards is required). However, an independent third party audit on-site as well as a stage on getting the certificate issued is the same for all certificates. However, Green Key uses another terminology as they don't call it 'to issue the certificate' but 'to award the Green Key'.

Green Key starts the process with a filling out an application form, where the client (i.e. the hotel management) has to self-assess to which degree the hotel complies with the Green Key criteria. Further, companies are asked to improve their compliance with criteria by $5 \%$ every year. The Green Key certificate is valid one year. A special characteristic for Green Key is that the awarded hotels (and other organizations) get visible on the website.

In order to keep Green Growth 2050 certification a given organization needs to undertake the annual assessment process conducted by a selected group of fully independent third-party auditors through an onsite assessment. Before the third party audit, the organization assesses how it complies with the criteria and submits requested documents. Annual registration is needed in order to make continues improvement and achieve higher levels of certification [41]. The standard includes over 400 CSR \& sustainability indicators. Businesses will be certified Silver, Gold or Platinum depending on their overall percentage achievement. Based on the data published in Internal Tourism Partnership, Minor Hotel Group's 35 properties under the Anantara Brand are all parts of Green Growth 2050.

Regarding Green Leaf, the main emphasis is on questionnaires. The first step is to answer the questions in a so-called 'Qualifying Questionnaire' aiming to assess the hotel on some basic resource and environmental management parameters. As soon as the completed Qualifying Questionnaire is returned from the applying hotel and accepted by the Green Leaf Foundation, the hotel will be given a 'Letter of Participation' and a 'Grading Questionnaire'. In the Grading Questionnaire, a set of 244 questions are listed to assess the hotel's role and 
involvement in promoting and developing the quality of life and environment in the community. The results of the assessment are compared with the reference standard score of the hotels. The standard score contains 20 reference hotels. Similar to Green Growth 2050, Green Leaf Certificate ranges from 1 to 5 (leaves), 5 representing the most practiced hotel in environmental management.

When it comes to ISO 14001, this certificate opens the process with an enquiry in a common process for the hotel (or other organization) and the certification body. Afterwards, the certification body has to confirm that the hotel (or other organization) can continue with the process. There are two stages of assessment, first as documentary review, and second an assessment on-site. In order for the certification and registration to take place, criteria have to be met. If they don't, they have to be improved. Annual surveillance is done, and renewal must happen every third year.

In Table 3 the overview of different characteristics among the five certifications is presented. Our research shows that Green Globe has the most detailed and ambitious level of assessment, however, this certificate has the lowest number of organizations certified.

The last method to differentiate among the five certifications was by looking at their criteria which can be seen in Table 4 where the findings of comparison for Green Globe, Green Key, Green Growth 2050 and ISO 14001 acroos their criteria are shown. Please notice that the Green Leaf Foundation is based on the questions through which it can be seen if the hotel complies with certain rules. It does not contain criteria that differentiate this certificate from the others. A detailed list of questions for Green Leaf is not given online; therefore the comparison including this particular certificate could not be done in Table 4. Please notice that 'to have indirect criteria' means that the criteria can only be assessed through other criteria. ISO 14001 has seven main requirements plus 36 others. As ISO 14001 is a general standard, meaning that it is applicable for all services and manufacturing, implies that it cannot have specific requirements on hospitality elements as the others have, especially Green Key. For instance, the difference is that Green Key requires food to be eco-labeled and organic (as well as the hotel is required to buy seasonal food, to consume less meat, and to decrease food waste), whereas the ISO 14001 standard just mention these elements indirectly by referring to protection of environment (e.g. ensuring that no contamination of water is taking place and thereby securing the food quality). Green Globe (four main requirements plus 41 others) doesn't focus on food and beverage and outdoor activities in details. Health and safety criteria differentiate for Green Globe where it's covering well-being of its customers and staff, while for ISO 14001 the same criteria mean to manage emergency situations, such as a fire, and in that specific way to take care of guests and employees. For indoor activity, last but not least, Green Key (13 main and 128 others) has a special section related to non-smoking. Overall, Green Key and Green Growth 2050 are the most similar ones, as they are focusing on the hotel industry. Nevertheless, Green Growth 2050 does not contain any regulation about the smoking policies.

Table 3. Characteristics of certificates

\begin{tabular}{|c|c|c|c|c|c|}
\hline Certifying body & $\begin{array}{l}\text { Different levels of } \\
\text { assessments? }\end{array}$ & Cost & $\begin{array}{l}\text { Monitoring and } \\
\text { Renewal }\end{array}$ & \# certified & $\begin{array}{c}\text { \# of } \\
\text { countries }\end{array}$ \\
\hline Green Globe & $\begin{array}{c}\text { Yes } \\
\text { (Certified, Gold or } \\
\text { Platinum) }\end{array}$ & $\begin{array}{c}\text { EUR 620-4200 } \\
\text { dependent on size plus } \\
\text { independent audit fees }\end{array}$ & $\begin{array}{l}\text { Annual renewal period, } \\
\text { standard is updated and } \\
\text { reviewed twice per year }\end{array}$ & 508 & 90 \\
\hline Green Growth 2050 & $\begin{array}{c}\text { Yes } \\
\text { (Silver, Gold or } \\
\text { Platinum) }\end{array}$ & $\begin{array}{c}\text { EUR } 720 \text { - } 3855 \\
\text { depending on size }\end{array}$ & $\begin{array}{c}\text { Member maintains } \\
\text { annual registration and } \\
\text { compliance promoting } \\
\text { continuous } \\
\text { improvement }\end{array}$ & $\begin{array}{l}\text { Minor Hotel } \\
\text { Group's } 35 \\
\text { properties }\end{array}$ & $\begin{array}{c}\text { Not } \\
\text { available }\end{array}$ \\
\hline $\begin{array}{c}\text { Green Key } \\
\text { Foundation for } \\
\text { Environmental } \\
\text { Education (FEE) }\end{array}$ & No & $\begin{array}{l}\text { EUR } 1000 \text { plus EUR } \\
500+\text { expenses for } \\
\text { audit }\end{array}$ & $\begin{array}{l}\text { Audits are conducted } \\
\text { first and second year } \\
\text { and then every three } \\
\text { years. GK is awarded } \\
\text { for one year at a time }\end{array}$ & 2400 hotels & $52-60$ \\
\hline $\begin{array}{c}\text { Green Leaf } \\
\text { Green Leaf Foundation, } \\
\text { Thailand }\end{array}$ & $\begin{array}{c}\text { Yes } \\
\text { (Letter of Participation, } \\
\text { Qualifying } \\
\text { Questionnaire or } \\
\text { Grading Questionnaire) }\end{array}$ & Not available & Two year review & $\begin{array}{l}230 \text { tourism } \\
\text { services }\end{array}$ & 1 \\
\hline $\begin{array}{c}\text { ISO } 14001 \\
\text { Various certifying } \\
\text { bodies accred. by } \\
\text { national accreditated } \\
\text { bodies }\end{array}$ & No & $\begin{array}{c}\text { Depends on audit time } \\
\text { and audit time depends } \\
\text { on client size and } \\
\text { complexity } \\
\text { (EUR 300-2000) }\end{array}$ & $\begin{array}{l}\text { Annual surveillance } \\
\text { minimum per year and } \\
\text { renewal in every three } \\
\text { years }\end{array}$ & $\begin{array}{l}1786 \text { hotels } \\
\text { and } \\
\text { restaurants }\end{array}$ & 186 \\
\hline
\end{tabular}

Source: provided by the authors. 
Table 4. Selected differences among the analyzed certifications

\begin{tabular}{|c|c|c|c|c|}
\hline Criteria & $\begin{array}{c}\text { Green } \\
\text { Globe }\end{array}$ & $\begin{array}{c}\text { Green } \\
\text { Key }\end{array}$ & ISO 14001 & Green Growth 2050 \\
\hline $\begin{array}{c}\text { Implement a Sustainability Management System } \\
\text { Sustainability management system that considers } \\
\text { environmental, sociocultural, quality, health, and safety } \\
\text { issues }\end{array}$ & $\checkmark$ & $\checkmark$ & $\begin{array}{c}\text { ONLY Environmental } \\
\text { issues }\end{array}$ & $\checkmark$ \\
\hline $\begin{array}{c}\text { Legal Compliance } \\
\text { In compliance with all relevant international or local } \\
\text { legislation and regulations (including, among others, } \\
\text { health, safety, labor, and environmental aspects) }\end{array}$ & $\checkmark$ & $\checkmark$ & $\begin{array}{c}\text { ONLY with } \\
\text { Environmental aspects }\end{array}$ & $\checkmark$ \\
\hline $\begin{array}{c}\text { Local Zoning, Design and Construction } \\
\text { Design and Construction - Compliance with Legal } \\
\text { Requirements; Sustainable Design and Construction of } \\
\text { Buildings and Infrastructure - New /Existing Buildings }\end{array}$ & $\checkmark$ & NO & $\checkmark$ & without local zoning \\
\hline $\begin{array}{c}\text { Health and Safety } \\
\text { Well-being of its customers, staff and local community }\end{array}$ & $\checkmark$ & $\checkmark$ & indirectly & $\checkmark$ \\
\hline $\begin{array}{c}\text { Social/Economic } \\
\text { Community Development, Local Employment, Support } \\
\text { Local Entrepreneurs, Respect Local Communities, } \\
\text { Exploitation, Equitable Hiring, Employee Protection }\end{array}$ & $\checkmark$ & $\checkmark$ & NO & $\checkmark$ \\
\hline $\begin{array}{c}\text { Fair Trade } \\
\text { Local and fair-trade services and goods are purchased by } \\
\text { the business, where available }\end{array}$ & $\checkmark$ & NO & NO & NO \\
\hline Food and Beverage & No & $\checkmark$ & indirectly & NO \\
\hline Indoor Environment & No & $\checkmark$ & NO \\
\hline
\end{tabular}

Further notice: Detailed information on the Green Leaf questionnaires could not be found.

Source: provided by the authors.

\section{Conclusions, Limitation and Further Research}

Existing research points to the positive effects as well as challenges of obtaining green certifications. The study revealed several different motivation factors for implementing green certificates. Our findings show that improving effectiveness and efficiency is the most significant motivation factor for all the hotels in the study. Further on, our research points to the likelihood that already received certifications (like ISO), the region (which could be due to competitors' actions when it comes to green certification) and/or the chain, the hotel belongs to (if it belongs to a chain) are motivation factors that will heavily influence decision makers when considering to apply for a green certificate.

In addition, we have identified differences across certifications, when it comes to different aspects like aim, process of certification, general characteristics and criteria. This was a reason for selection choice for one of the hotels.

The limitations of this research are: (1) only few hotels were involved in the study; (2) convenience sampling - a more systematic approach would be recommendable in follow-up research; (3) limited amount of primary data; (4) the general and quality managers were giving answers based on their perception or gut-feeling, with limited reference to objective data, due to the questionnaire/interview guide's character'; and (5) the choice of the questions in the interviews could also be a limitation factor.
In future studies, we would suggest comparative studies related to green certification usage in more countries and regions. Moreover, our own research could be repeated with interviews in more hotels. Monitoring the future development of the green certificates in the already interviewed hotels could also be done. In addition, the guests of the certified hotels could also be made participants of such research, which would allow insight of their points of view as to how they perceive customer satisfaction and how they would assess situations before and after the implementation of the certificate-induced changes. Also, comparisons between hotels' and guests' motivation factors would be interesting.

The managerial implication of this study could be the aggregated insight into the motivation and the diversity of green certification represented by different viewpoints of the general manager, quality manager and assigned person.

As a further recommendation, we believe that it would be interesting to examining how voluntary certifications (like green certificates) are associated with corporate branding. Further, we have identified that there is a research gap when it comes to insights in the implementation and operation of the green certificates. Finally, it can be interesting to see what is it impact on the triple bottom line.

\section{Acknowledgements}

The authors would like to thank the interviewees in the research. Further, we would like to thank Mr. Peter Sunley, 
adjunct professor at Webster Vienna Private University, for his input on data collection in the hotels in Thailand and Maldives.

\section{REFERENCES}

[1] Pizam A, Shani A. The nature of the hospitality industry: present and future managers' perspectives. Anatolia. 2009; 20(1):134-50.

[2] Martín-Peña ML, Díaz-Garrido E, Sánchez-López JM. Analysis of benefits and difficulties associated with firms' Environmental Management Systems: the case of the Spanish automotive industry. Journal of Cleaner Production. 2014; 70:220-30.

[3] Martín - de Castro G, Amores - Salvadó J, Navas - López JE. Environmental management systems and firm performance: improving firm environmental policy through stakeholder engagement. Corporate social responsibility and Environmental Management. 2016; 23(4):243-56.

[4] Thomsen FB. Implementation of green practices is valuable for Danish hotels. 2017. Available from: http://www.greenkey.global/stories-news-1/2017/2/3/imple mentation-of-green-practices-is-valuable-for-danish-hotels [Accessed 2nd May 2018].

[5] Borella IL, Borella C, Rodrigues M. Environmental Impact and Sustainable Development: An Analysis in the Context of Standards ISO 9001, ISO 14001, and OHSAS 18001. Environmental Quality Management. 2016; 25(3):67-83.

[6] De Jong P, Paulraj A, Blome C. The financial impact of ISO 14001 certification: top-line, bottom-line, or both? Journal of Business Ethics. 2014; 119(1):131-49.

[7] Graafland JJ. Ecological impacts of the ISO14001 certification of small and medium sized enterprises in Europe and the mediating role of networks. Journal of Cleaner Production. 2018; 174:273-82.

[8] Graci S, Dodds R. Why go green? The business case for environmental commitment in the Canadian hotel industry. Anatolia. 2008; 19(2):251-70.

[9] He W, Liu C, Lu J, Cao J. Impacts of ISO 14001 adoption on firm performance: Evidence from China. China Economic Review. 2015; 32:43-56.

[10] Sasidharan V, Sirakaya E, Kerstetter D. Developing countries and tourism ecolabels. Tourism Management. 2002; 23(2):161-74.

[11] Hasek G. 2013 - The greenest year yet for our industry? Green Lodging News. 2013. Available from: http://www.green lodgingnews.com/2013-the-greenest-year -yet-for-our-industry/ [Accessed 2nd May 2018].

[12] UNWTO. United Nations declares 2017 as the International Year of Sustainable Tourism for Development [Press Release]. 2017. Available from: http://media.unwto.org/press-release/2015-12-07/united-na tions-declares-2017-international-year-sustainable-tourism -develop [Accessed 2nd May 2018].
[13] Weeden C. Ethical tourism: An opportunity for competitive advantage? Journal of Vacation Marketing. 2002; $8(2): 141-53$.

[14] Tzschentke NA, Kirk D, Lynch PA. Going green: Decisional factors in small hospitality operations. International Journal of Hospitality Management. 2008; 27(1):126-33.

[15] Chan E SW. Gap analysis of green hotel marketing. International journal of Contemporary Hospitality Management. 2013; 25(7):1017-48.

[16] Prendergast G, Man HW. The influence of store image on store loyalty in Hong Kong's quick service restaurant industry. Journal of Foodservice Business Research. 2002; $5(1): 45-59$.

[17] Pizam A. Green hotels: A fad, ploy or fact of life? International Journal of Hospitality Management. 2009; 28(1): 1 .

[18] Knuth S. Seeing green in San Francisco: City as resource frontier. Antipode. 2016; 48(3):626-44.

[19] Kasim A. Socially Responsible Hospitality and Tourism Marketing. In: Oh H, Pizam, A (eds.), Handbook of Hospitality Marketing. Boston, MA: Butterworth-Heinemann; 2009. p. 32-58.

[20] Luan CJ, Tien C, Chen WL. Which "green" is better? An empirical study of the impact of green activities on firm performance. Asia Pacific Management Review. 2016; 21(2):102-10.

[21] Black R, Crabtree A. (eds.) Quality Assurance and Certification in Ecotourism. Wallingford: Cabi Publishing; 2007.

[22] Morris N. Sustainability: What is it? Power Engineer. Academic Search Power Engineer. 2004; 18(5): 11.

[23] Green Globe.Green Globe International, Inc. (n.d.). Available from:

http://pathwaytosustainability.org/green-globe-internationa 1-inc/ [Accessed 2nd May 2018].

[24] Dief ME, Font X. The determinants of hotels' marketing managers' green marketing behaviour. Journal of Sustainable Tourism. 2010; 18(2):157-74.

[25] López-Gamero MD, Molina-Azorín JF, Claver-Cortés E. The potential of environmental regulation to change managerial perception, environmental management, competitiveness and financial performance. Journal of Cleaner Production. 2010; 18(10-11):963-74.

[26] Gagiolli, A. Eco-Friendly hotel certifications overview. 2015. Available from:

https://www.cloudbeds.com/articles/eco-friendly-hotel-cert ifications-overview/ [Accessed 2nd May 2018].

[27] Fukey LN, Issac SS. Connect among green, sustainability and hotel industry: a prospective simulation study. Energy Conservation. 2014; 6:8.

[28] Li S, Jayaraman V, Paulraj A, Shang KC. Proactive environmental strategies and performance: role of green supply chain processes and green product design in the Chinese high-tech industry. International Journal of Production Research. 2016; 54(7):2136-51. 
[29] Zhang JJ, Joglekar Ph D N, Verma Ph D R, Heineke J. Exploring the Relationship between Eco-certifications and Resource Efficiency in US Hotels. [Electronic article]. Cornell Hospitality Report. 2014; 14(7):6-16.

[30] Sedmak G. Keynote Speech presented at the International Tourism and Hospitality Management Conference, Belgrade, Serbia. 14 ${ }^{\text {th }}$ September 2017.

[31] Dippold T, Mutl J, Zietz J. Opting for a green certificate: the impact of local attitudes and economic conditions. Journal of Real Estate Research. 2014; 36(4):435-73.

[32] Granly BM, Welo T. EMS and sustainability: experiences with ISO 14001 and Eco-Lighthouse in Norwegian metal processing SMEs. Journal of Cleaner Production. 2014; 64:194-204.

[33] Font X. Environmental certification in tourism and hospitality: progress, process and prospects. Tourism Management. 2002; 23(3):197-205.

[34] Bergin M. Manage your environmental costs. Hotel \& Catering Review. 2010; 33-35.

[35] Tsai T, Chan LC, Chou KH, Schultz M, Heike F, Yeung KY. Island Shangri-La's Environmental Management System: A Long Way to Go! Asian Case Research Journal. 2003; 7(02):173-94.

[36] Reiser A, Simmons DG. A quasi-experimental method for testing the effectiveness of ecolabel promotion. Journal of Sustainable Tourism. 2005; 13(6):590-616.

[37] Font X. Demand for certification according to consumer demand experts and consumer advocacy organizations. Report of The International Ecotourism Society, presented in Washington DC. January 2005.

i An early version of this article was presented at the the $3^{\text {rd }}$ International Tourism and Hospitality Management Conference (ITHMC 2017) in Belgrade, Serbia, 13-17 Sept. 2017.
[38] Koeppel D. Awards, standards and certification - what's the difference? 2017. Available from: http://danielkoeppelanda ssociates.com/sustainability/how-sustainabilty-helps-increa se-the-bottom-line/awards-standards-and-certification-wha ts-the-difference [Accessed 2nd May 2018].

[39] Sile A.W. Thailand is Asia Pacific's most popular tourist destination: MasterCard. 2016. Available from: https://www.cnbc.com/2016/01/27/thailand-is-asia-pacifics -most-popular-tourist-destination-says-mastercard.html [Accessed 2nd May 2018].

[40] Scheyvens R. The challenge of sustainable tourism development in the Maldives: Understanding the social and political dimensions of sustainability. Asia Pacific Viewpoint. 2011; 52(2):148-64.

[41] International Tourism Partnership. Know How Guide: Sustainable Hotel Certification Schemes. 2016. Available from:

http://www.scpclearinghouse.org/sites/default/files/khg_ce rtifications.pdf [Accessed 2nd May 2018].

[42] Environmental management system - Requirements [Brochure]. Belgrade, Serbia: Institute for Standardization of Serbia. 2015.

[43] Sanorlam S, Thawesaengskulthai N. Integrated quality safety and environmental management system for concrete roof manufacturer. In Industrial Engineering and Applications (ICIEA), 2017 4th International Conference on 2017 Apr 21 (pp. 255-259). IEEE.

[44] Oliveira JA, Oliveira OJ, Ometto AR, Ferraudo AS, Salgado MH. Environmental Management System ISO 14001 factors for promoting the adoption of Cleaner Production practices. Journal of Cleaner Production. 2016; 133:1384-94 